\title{
Analyzing the Island Province Policy on Poverty Alleviation in Maluku Province*
}

\author{
Yayan Satyakti \\ Department of Economics \\ Universitas Padjadjaran (UNPAD) \\ Bandung, Indonesia \\ yayan@unpad.ac.id \\ Eksa Pamungkas \\ Department of Economics \\ Universitas Padjadjaran (UNPAD) \\ Bandung, Indonesia \\ eksa.pamungkas@unpad.ac.id
}

\author{
Irlan Adiatma Rum \\ Department of Economics \\ Universitas Padjadjaran (UNPAD) \\ Bandung, Indonesia \\ irlan.rum@unpad.ac.id \\ Estro Sihaloloho \\ Department of Economics \\ Universitas Padjadjaran (UNPAD) \\ Bandung, Indonesia \\ estro.sihaloho@unpad.ac.id \\ Jacobacus D. Rijoly \\ Department of Economics \\ Universitas Pattimura Ambon
}

\begin{abstract}
This paper investigates the effects of island province policy based on Law No. 23 Year 2014 on Regional Autonomy particularly in article No. 27. It is stated that the island province has additional jurisdiction to manage maritime cadastral zone up to 12 miles from the coastline. To measure its influence, policies are differentiated with or without additional marine boundary areas that affect the coastal zone economic development. To estimate the cadastral zone potential, the growth of chlorophyll area is calculated as a proxy of in site economic potential for regional development.
\end{abstract}

Keywords-spatial enometrics, chlorophyll concentration, village fund transfer.

\section{INTRODUCTION}

This paper investigates the effects of island province policy based on Law No. 23 Year 2014 on Regional Autonomy in particular article No. 27 about Island Province definition. Focus point of this paper is developing model of island economic activities on poverty alleviation in Maluku Province.

This paper is close to [1] where ecosystem services and its economic values are affected by household activities. They develop causal pathways between conservation actions and environmental outcomes. These impacts should be translated into changes in ecosystem services through spatial variability of impact on carbon storage in Brazil, Costa Rica, Indonesia and Thailand. The study was conducted by cost-benefit analysis that delivered ecosystem services due to deforestation. Assessing with different contexts from previous studies is done which is based on hypothesis that poverty has strong relationship with rapid loss biodiversity [2].

The transmission analysis between Island Province Policy and poverty alleviation examines the ecosystem services of biodiversity conservation on coastal zone economics which is affected by poverty traps. This issue is important because according to BPS (2017) $)^{1}$, eastern part of Indonesia has vast natural resources based on maritime resources. Unfortunately, the regions are remained left behind compared to the central and west regions of Indonesia especially in Maluku Province. Therefore, this paper is elucidating whether poverty alleviation improvement exists if island province policy is applied in Maluku Province.

\section{LITERATURE REVIEW}

\section{A. Ecosystem Services in Coastal Zone}

Humans benefit from ecosystem of endowment and entitlements, as a capital: natural, social, human, financial, and physical, preferences, means other than ecosystem services. Endowments, entitlements and capitals play a vital role in access; while human preferences affect the ecosystem character in human dominated landscapes [3]. The framework differentiates services between how they are accessed and controlled. The distinction between ecosystem services that are physical entities (i.e. cash provisioning services) and a second group includes regulating, cultural, and supporting services. The framework supports people to benefit cash from commoditized services, as opposed to direct services. Ecosystem services can access payments. When people are unable to access non-commoditized services, they cannot obtain direct payment services. Limitation and restriction of these conditions (i.e. control and access of endowment, entitlements, and capitals) lead to lose access to direct services and increase poverty due to losing assets of biodiversity.

\footnotetext{
1 https://www.bps.go.id/linkTableDinamis/view/id/1219
} 
This study focuses on biodiversity loss in coastal zone biodiversity in islands area. Several important issues to be addressed in Maluku Province are: a) many fish farmers in Maluku Provinces are in subsistence level and small-scale fisheries cultivation. These fish farming activities are highly dependent on the aquaculture sector which relies on marine ecosystem services [4]. According to recent studies [5] coastal areas are the most vulnerable areas in the adverse effects of climate change. This impact has negative externalities on poor household in Bangladesh. b). [6] reported in Ambon Coastal Zone, the fish farmers cannot catch fish within 20 miles distance from the coastline. It is noted that the fish catchment zone has shifted towards advance zone beyond 20 miles. This phenomenon suggets [7] that climate change has decreased production of organic matter which supports all marine ecosystems in chlorophyll concentration. [8] It is reported that climate change has reduced net primary production that is photosynthesis by oceanic phytoplankton. These growth limiting factors reduce marine ecosystems which restrict physical processes of ocean circulation, dynamic mixed-layer, upwelling, atmospheric dust deposition and the solar cycles within surface layer of marine ecosystem.

\section{B. Climate Change and Social Vulnerability in Coastal Communities}

As discussed earlier, climate change affects coastal zone area; especially fish farmers since climate change has impact on ocean productivity and decreases marine ecosystem productivity as well as reduces payment ecosystem services (PES) for fish farming. [9] a case in the United States reports that coastal communities are increasingly pressured by the effects of climate change that has a direct impact on the availability of fish stock due to changes in ocean temperature and acidification.

They developed practical indicators of Community Social Vulnerability Indicators (CSVIs) i.e. community social vulnerability indices (e.g. personal disruption index, labor force structure index, commercial fishing engagement index, poverty index, housing characteristic index, and commercial fishing reliance index); community climate change indices (e.g. sea level risk, sea level rise and business affected, species vulnerability and catch composition diversity).

They measured the impacts using Generalized Linear Model (GAM) to estimate the timing of both linear trends as well as non-monotonic responses. The chlorophyll (Chl) estimation employed through model is as follow:

$$
\eta(\mu)=\beta_{0}+\beta_{\text {year year }}+\beta_{1} x_{1, i}+f_{1}\left(x_{2, i}\right)+f 2\left(x_{3, i}, x_{4, i}\right)+\varepsilon_{i}
$$

where $i$ is the individual observation, $\eta$ is the monotonic link function of the expected mean Chl concentration, $\mu_{\mathrm{i}}$, year, $\mathrm{x}_{1}, \mathrm{x}_{2}, \mathrm{x}_{3}$ and $\mathrm{x}_{4}$ are predictors variables, $\beta_{0}$ is the model intercept, $\beta$ denotes parametric and $\mathrm{f}$ denotes functional effects estimated from the data, and $\varepsilon_{\mathrm{i}}$ represents the residual error term.

This indicator impacts on potential business risk in the seafood commerce sector which affects the business revenue in coastal areas. Decrease in ocean chlorophyll impacts on the local economic business sectors; rural economic revenue declines due to the loss of chlorophyll ecosystem services.

\section{Policy Analysis of Poverty Alleviation}

As noted earlier, policy analysis is conducted by analyzing Island Province Policy. In article No. 27 Law No. 23 Year 2014 which stated that island provinces have additional authority to manage maritime cadastral zone up to 12 miles beyond coast line. Following policy analysis according to [10], modelling effect of policies is conducted by simple equation that is:

$$
\delta p / \mathrm{d} p \geq 0 \text { where } p^{*}<p_{\mathrm{BAU}}
$$

$\delta$ is change of policy between poverty of policy affect ( $\mathrm{p}^{*}$ ) smaller than poverty of business as usual (BAU). Increasing in $\delta p / \mathrm{d} p$ less than 0 where improving of island policy will increase poverty alleviation.

\section{DATA}

Two types of databases are applied in order to measure the policy analysis. The databases consist as follow:

1. Spatial database comprises of land use change database and ocean resource database. Land use data are retrieved with 100.000 scales with projected Mercator World Projection (the data were obtained from Indonesia Geospatial Database). The ocean database was obtained from NASA chlorophyll database with 4 band density ${ }^{2}$. Land use change data were collected from 2005 to 2014. The database was adjusted into parcel land use unit analysis by $10^{\circ} \mathrm{x} 10^{\circ}$ which disaggregated into 70.020 parcels for each cross section with three sets of databases $(2005,2010$, and 2014) of island in Maluku Province. Decomposition of land use is distinguished according to land use classifications which are in line with economics sectors such as agriculture, manufacture, residence and commercial;

2. Non spatial database comprises of macroeconomics indicators database as an anchor of land use composition trajectory towards 2021. These indicators (e.g. Gross Domestic Product, Private Consumption, Gross Fix Capital Formation, Government Consumption, Export, Import, Labor Force, Investment, and Sectoral Output) were employed within 14 years period across 9 municipalities (rural area classification, "kabupaten") and 2 regencies (urban area classification, "kota"). The data were retrieved from Maluku Statistical Agency (Badan Pusat Statistik Provinsi Maluku).

\footnotetext{
2 https://oceancolor.gsfc.nasa.gov/cgi/browse.pl?sen=am
} 
3. 3. In addition to macroeconomic indicators, interisland trade activities are estimated through export and import trading activities. The interisland trade density is estimated through the traffic of shipping activities within two years with the frequency of daily activities. This data can be retrieved from https://www.marinetraffic.com.

4. The poverty data were obtained spatially from Village Potential Data (PODES) where village data level was synchronized into administrative level village database provided by BPS as well. The PODES data are essential for aligning poverty data with spatial database. These administrative boundaries spatial as well as PODES data will be attached into parcel data for both land use as well as ocean database.

\section{MODEL SETUP AND METHODS}

The analysis is done by incorporating several steps before evaluating the policy analysis. The pivotal point in the estimation is business-as-usual forecasting for both economic indicators and spatial expansion. The economic indicators will estimate the future of sectorial compositions such as agriculture, manufacture, services and residence sector.

\section{A. Model Setup}

The demand function drives the supply function for each sector across island cluster in Maluku Province. Output forecasting in macroeconomics indicators is extrapolated towards 2021 through panel Vector Auto-regression as an anchor for estimating demand of land use change. A macro model is estimated through:

$$
Q^{*}{ }_{t, r}=f\left(C_{t, r}, I_{t, r}, G_{t, r} \boldsymbol{T}_{t, r}\right)
$$

where $\mathrm{Q}_{t r}$ is output in cluster island across Maluku Province, $\mathrm{C}_{\mathrm{tr}}$ is private consumption, Itr is investment sectors, Gtr is government expenditure, and Ttr is intra+inter trade activities between islands and outside of Maluku Province. The Ttr estimated through gravity equation as noted in [11] given by,

$$
\mathbf{T}_{\mathbf{t}, \mathbf{r}, \mathbf{r}}=\ln \mathrm{X}_{\mathrm{r}}{ }_{\mathrm{X}} \mathrm{X}_{\mathrm{s}}=\mathrm{S}_{\mathrm{i}}-\mathrm{S}_{\mathrm{n}}-\theta_{\mathrm{rs}}-\theta_{\mathrm{d}}-\theta_{\mathrm{b}}-\theta_{\mathrm{e}}+\varepsilon_{\mathrm{r}}
$$

where $\mathrm{X}$ is export of an island cluster to other island clusters as well as export outside Maluku, $S_{i}$ is island competitiveness as a technology adjusted for its labor cost, proxied by Human Development Index in each island cluster, and $S_{n}$ is otherwise. $\theta$ represents percentage cost increase for each imposes, the $\theta$ follow iceberg transportation cost assumption for each trade parameters in $r s$ from island cluster to other cluster. $\mathrm{d}$ for the distance, $\mathrm{b}$ for sharing border with binary value that 1 share border, 0 for not sharing border. e is trading special zone for island cluster. following the production function connected between economic and spatial data

$$
\mathrm{Q}^{*} \mathrm{tr}=\mathrm{f}\left(\mathrm{K}_{\mathrm{tr}}, \mathrm{L}_{\mathrm{tr}}, \lambda_{\mathrm{tr}}\right)
$$

Where $\mathrm{Q}^{*}$ is output forecasting in each sectoral composition across sectors. So land demand to stimulate growth by adopting applying equation (4) into

$$
\lambda *_{\mathrm{itr}}=\partial \lambda_{\mathrm{itr}} / \partial \mathrm{Q}{ }_{\mathrm{tri}}=\mathrm{f}\left(\mathrm{Q} *_{\text {tri }}\right)
$$

where $\mathrm{t}_{\mathrm{ri}}$ is land use composition for $i$ parcel, in region $r$ within period of $t$. Whilst $\lambda{ }^{*}$ itr is land use assets which is evaluated through Payment Ecosystem Services (PES) as conducted by [12]. The values of changing $\lambda *_{\text {itr }}$ for both land use and ocean coastal zone estimated through these following equations,

$$
\begin{aligned}
\mathrm{LU}_{\mathrm{itr}} & =\lambda *_{\mathrm{itr}} \times \mathrm{PES}_{\mathrm{LU}} \\
\mathrm{OCU}_{\mathrm{itr}} & =\Omega *_{\mathrm{itr}} \times \mathrm{PES}_{\mathrm{OCU}}
\end{aligned}
$$

Where LU is terrain land use multiplied by PES with terrain land use values as stated in [12]. OCU is ocean cadastral use consist of $\Omega *_{\text {itr }}$ with respect to chlorophyll estimation given by

$$
\Omega *_{\text {itr }}=\eta(\mu) \times \text { PES }_{\text {OCU }}
$$

for both $\mathrm{LU}_{\text {itr }}$ and $\mathrm{OCU}_{\text {itr }}$ incorporate into poverty model that escaping of poverty (define in binary probability of poverty) is a function of natural resource assets and income of households [2],

$$
\mathrm{P}\left(\pi_{\mathrm{itr}}=(1,0)\right)=\mathrm{f}\left(\mathrm{Y}_{\mathrm{itr}}, \mathrm{A}_{\mathrm{itr}}\right)
$$

Where $\mathrm{P}\left(\pi_{\text {itr }}\right)$ is probability of poor in parcel $\mathrm{i}$ within period of $\mathrm{t}$ in region $r$, where $r$ is village level. $Y_{\text {itr }}$ is household income in parcel $\mathrm{i}$, within period $t$ in region $r$, where assets $\left(\mathrm{A}_{\text {itr }}=\mathrm{f}\left(\mathrm{LU}_{\mathrm{itr}}\right.\right.$, $\left.\mathrm{OCU}_{\text {itr }}\right)$ ). The policy impact scenarios according to article No. 27 Law No. 23 Year 2014 can be assessed through this equation,

$$
\begin{gathered}
\mathrm{P}\left(\pi_{\text {itr }}\right)_{\mathrm{BAU}}=\mathrm{f}\left(\mathrm{Y}_{\mathrm{itr}}, \mathrm{A}_{\mathrm{itr}}\right) \\
\mathrm{P}\left(\pi^{*_{\text {itr }}}\right)_{\mathrm{POLICY}}=\mathrm{f}\left(\mathrm{Y} *_{\text {itr }}, \mathrm{A}^{*}{ }_{\text {itr }}\right)
\end{gathered}
$$

The policy impact is $\mathrm{P}\left(\pi^{*} \text { itr }\right)_{\mathrm{POLICY}}<\mathrm{P}\left(\pi_{\mathrm{itr}}\right)_{\mathrm{BAU}}$ there is significance of $\delta \mathrm{P}\left(\pi_{\text {itr }}\right)=\mathrm{P}\left(\pi^{*} \text { itr }\right)_{\mathrm{POLICY}}-\mathrm{P}\left(\pi_{\mathrm{itr}}\right)_{\mathrm{BAU}}$ where $\delta \mathrm{P}\left(\pi^{*} \text { itr }\right)_{\text {POLICY }} / \delta \mathrm{P}\left(\pi_{\text {itr }}\right)_{\mathrm{BAU}}<0$.

\section{B. Methods}

The first step of estimation is forecasting Business as Usual as a baseline scenario forecasted from 2017 towards 2021The equations used for estimation are as follow: In the beginning of forecasting, equation 2 is estimated by Panel VAR to forecast output $\left(Q^{*}\right)$. From this estimation decomposed sectoral composition inline with historical share and forecasted along with equation (2);

1. Equation (3) following [11] by employing forecasting of export and import $\mathbf{T}_{\mathbf{t r}}$ is re-estimated by gravity equation as noted by [11];

2. The output $\left(\mathrm{Q}^{*}\right)$ also affects factors of production demand such as land demand, as noted in equation [5]. This equation is estimated through Bayesian probity analysis to get $\lambda *_{\text {itr; }}$;

3. The value of $\lambda *_{\text {itr }}$ is converted and multiplied to $\mathrm{PES}_{\mathrm{LU}}$ whilst $\mathrm{OCU}_{\text {itr }}$ is measured through equation $\eta(\mu)=\beta_{0}+\beta_{\text {year }}$ year ${ }_{i}+\beta_{1} x_{1, i}+f_{1}\left(x_{2, i}\right)+f 2\left(x_{3, i}, x_{4, i}\right)+$ $\varepsilon_{\mathrm{i}}$ [7] through employing GLM method;

4. Equations (10) and (11) are estimated by Bayesian panel probity analysis to estimate $\mathrm{P}\left(\pi_{\mathrm{itr}}\right)_{\mathrm{BAU}}$ that later on simulating similar equation with improving village fund transfer due to increasing revenue island province by enacting Law No. 23 Year 2014 that 
creates new $\mathrm{A} *_{\text {irt }}$ and $\mathrm{Y} *_{\text {irt. }}$ It is assumed that revenue from enacting article No. 27 Law No. 23 Year 2014.

\section{RESULTS}

After the estimation process from steps (1) - (5), the forecasting results shows in estimation map towards land use map year 2021 as shown in Figure 1.

Fig. 1. Terrain Map Projections in 2021.

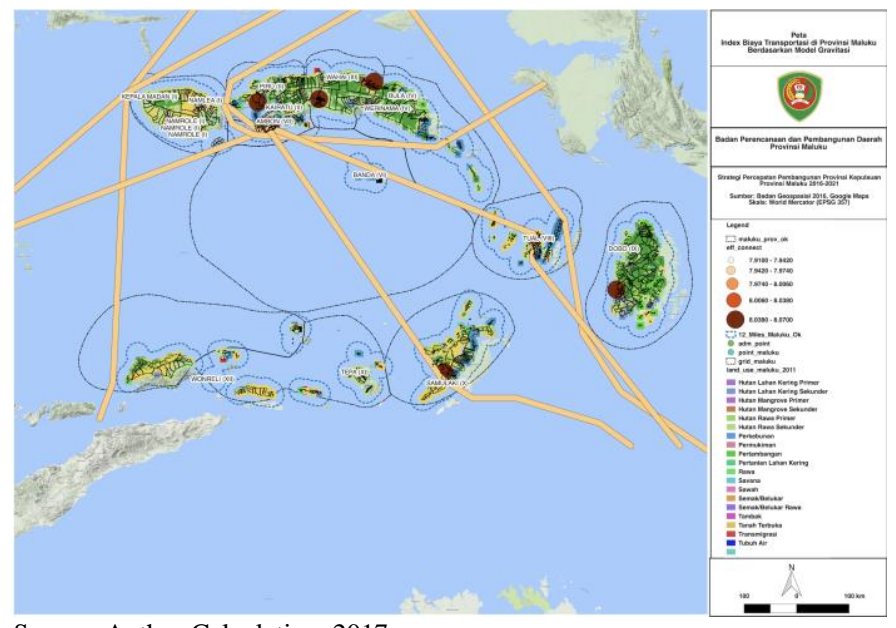

Source: Author Calculation, 2017

The estimation results are presented in forecasting maps rather than econometrics, due to small space in this paper. According to baseline results as shown in Figure 1, Buru Island Cluster and South East Island Cluster will be more advance rather than other island clusters. Improving connectivity between islands and decreasing transportation cost in these areas will improve economic activities by labor migration between these island-clusters. In ocean cadastral space, the chlorophyll has been sifted into advanced, as noted earlier by [6].

Fig. 2. Decreasing of Ecosystem Services Productivity surrouding 12 miles due to shift beyond 12 miles. Chlorophyll in 2015

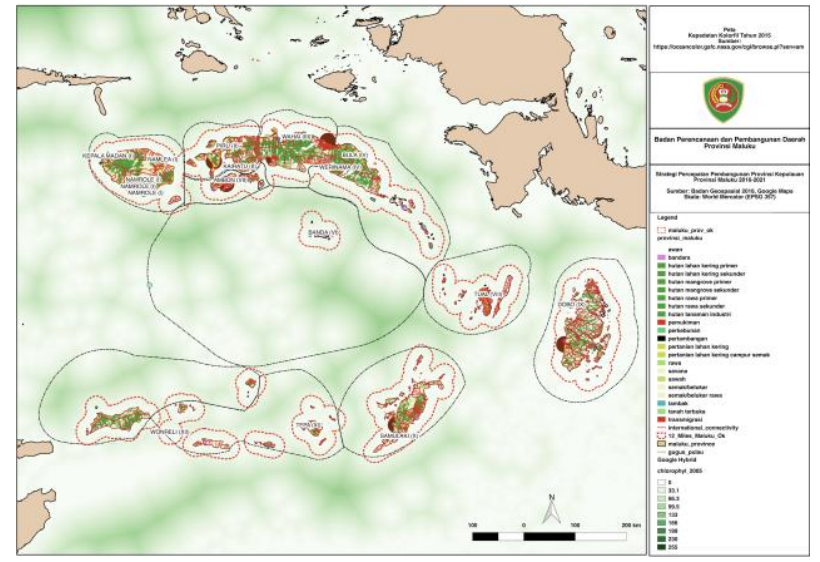

Source: Author Calculation, 2017.
Comparing to previous condition in 2005 , it is shown that across areas in Maluku Province

Fig. 3. Ecosystem Services Productivity surrouding 12 miles due to shift beyond 12 miles. Chlorophyll in 2005

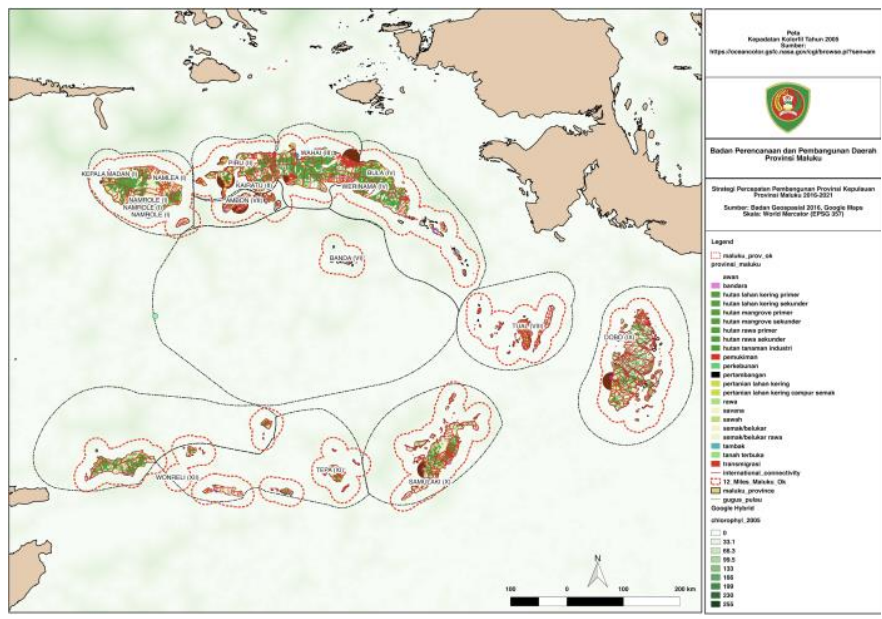

Source: Author Calculation, 2017.

From both Figure 2 and Figure 3, it can be seen that $\mathrm{OCU}_{\text {irt }}$ has been shifted and concentrated beyond 12 miles. The decrease of Ecosystem Services within cadastral zone without policy estimation $\left(\mathrm{OCU}_{\text {irt }}\right.$ calculated only in coastal zone - 1-5 miles) results in lowered Payment Ecosystem Services for household in coastal zone area. From these database then estimations for equation (6) and (7) are calculated. The results from these estimates are fed into poverty model as noted in equation (10) and (11). The estimation shows that the probability of escaping poverty without any policy intervention in Maluku Province is about $-3 \%$. This value indicates that the probability of a baseline estimation of poverty reduction is only $3 \%$ over a four-year period.

TABLE I. MEAN POVERTY PROBABILITY WITHIN PERIOD 2017 - 2021.

\begin{tabular}{|c|c|c|}
\hline Escaping of Poverty & Baseline & Scenario \\
\hline Probabillity of Escaping & $-3 \%$ & $-7 \%-9.5 \%$ \\
\hline
\end{tabular}

In order to compare the policy, a simulation is conducted on regional transfer to incorporate island province policy which includes the assets of 12 miles cadastral zone in each islands cluster. The $\mathrm{OCU}_{\text {irt }}$ for $\mathrm{PES}_{\text {irt }}$ is done in each parcel of cadastral zone as economic potential revenue. Another simulation is run to potential revenue allocated into each village in Maluku Province. There are four basic fund transfers as priorities to improve rural development; those are (A recommendation based on Focus Group Discussion):

1. The total number of poor household is above the average of poor household in Maluku Province;

2. Economic empowerment in maritime sectors; every village is expected to at least have maritime local enterprises. The activities include business 
development, capacity building of local community, and market introduction;

3. Technological appropriateness; every farmers and fish farmers should be assisted by skill programs to promote local technology;

4. Increasing availability of energy access through local technology and renewable.

The funding transfer is allocated by $60 \%$ of basic fund which is distributed equally without any condition; and adding $40 \%$ of allocation transfer according econometric estimation in equations 10 and 11 . The result shows that in 2021, the poverty alleviation would improve as shows in Table 1. The transfer allocation program likely reduces poverty than business as usual. .

Fig. 4. Program Priority in Village in 2021

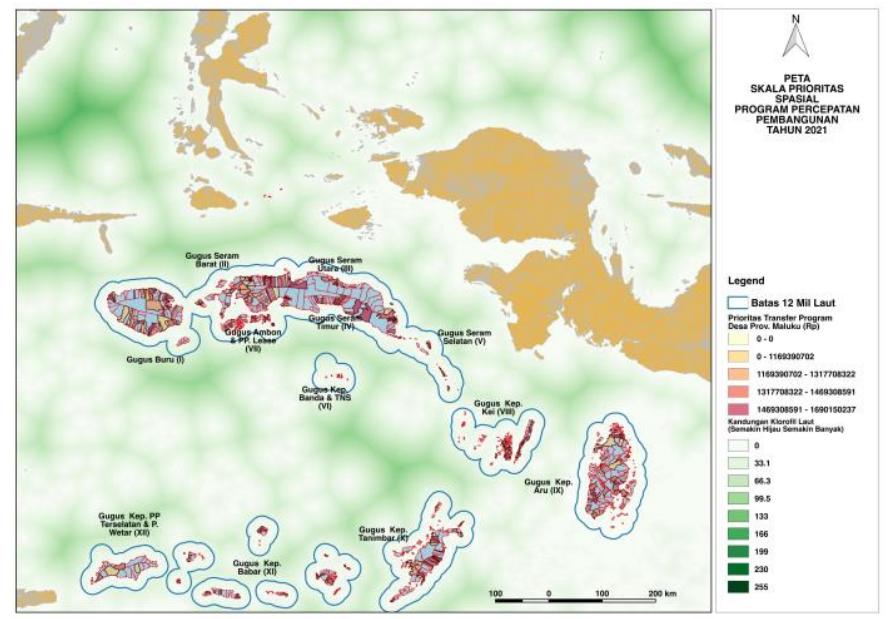

Source: Author Calculation, 2017.

\section{CONCLUSION}

It is concluded that direct policy on local community empowerment will decrease poverty in rural area. In Maluku Province, direct policy of government transfer on local economic empowerment is crucial to improve poverty alleviation. Climate change decreases economic potential revenue from cadastral zone policy. Although in article 27 Law No. 23 Year 2014, it is stated that island province has additional potential revenue to manage their cadastral zone; climate change has shifted ecosystem service beyond 12 miles. Therefore, the policy would be less benefit than 10 years ago. Direct transfer policy should accommodate people need especially for maritime sectors and renewable energy in Maluku Province.

\section{ACKNOWLEDGMENT}

An acknowledgement is sent to Maluku Province Planning Agency for financing this research as a part of project Strategic Agenda for Development Acceleration Program in Maluku as an Island Province.

\section{REFERENCES}

[1] Ferraro, Paul. J, Merlin M. Hanauer, Daniela A. Miteva, Joanna L. Nelson, Subhrendu K. Pattanayak, Christoph Nolte, Katharine R.E. Simms, "Estimating the Impacts of Conservation on Ecosystem Services and Poverty by Integrating Modeling and Evaluation", Proceding of National Academy of Science, vol. 112, no.24, pp. 7420-7425, 2015.

[2] Barret, Chirstopher. B, Alexander J. Travis, Partha Dasgupta,"On Biodviersity Conservation and Poverty Traps",Proceeding National Academy of Sciences, vol. 108, no. 34, pp.13970-13912, 2011.

[3] Fisher, Janet A., Genevieve Patenaude, Kalpna Giri, Kristina Lewis, Patrick Meir, Patricia Pinho, Mark D.A. Rounsevell, Mathew Williams, "Understanding the Relationships between Ecosystem Services and Poverty Alleviation: A conceptual framework", vol. 7, pp.34-45,2014.

[4] Kawarazuka, Nozomi., Christope Bene, "Linking Small-Scale Fisheries and Aquaculture to Household Nutrional Security: An Overview", Food Security, vol. 2, pp. 343-357, 2010.

[5] Dasgupta, Susmita., Mainul Huq, Md. Golam Mustafa, Md. Istiak Sobhan, David Wheeler, "The Impact of Aquatic Salinization on Fish Habitats and Poor Communities in a Changing Climate: Evidence from Southwest Coastal Bangladesh", Ecological Economics, vol. 139, pp. 128-139, 2017.

[6] Khouw, Abraham Semuel, "Potensi Maritim dan Pengelolaan Sumber Daya Alam di Provinsi Maluku”, Workshop Forum Investasi Percepatan Pembangunan Provinsi Kepulauan Maluku, 2016.

[7] Boyce, Daniel G., Mmichael Dowd, Marlon R. Lewis, Boris Worm, "Estimating Global Chlorophyll Changes over the Past Century", Progress in Oceanography, vol. 122, pp.163-183, 2014.

[8] Behrenfeld, Michael J., Robert T. O’Malley, David A. Siegel, Charles R. McClain, Jorge L. Sarmiento, Gene C. Feldman, Allen J. Milligan, Paul G. Falkowski, Ricardo M. Letelier, Emmanuel S. Boss, "Climate-drive Trends in Contemporary Ocean Productivity", Nature, vol. 444, pp. 752755, 2006.

[9] Colburn, Lisa L., Michael Jepson, Changhua Weng, Tarsila Seara, Jeremy Weiss, Jonathan A. Hare, "Indicators of Climate Change and Social Vulnerability in Fishing Dependent Communities along the Eastern and Gulf Coast of the United States", Marine Policy, vol. 74, pp. 323-333.

[10] Shahidur, Khandker R., Gayatri B. Koolwal, Hussain A. Samad, "Handbook on Impact Evaluation: Quantitative Methods and Practices", The World Bank, 2010.

[11] Eaton, Jonathan., Samuel Kortum., "Technology Geography and Trade", Econometrica, vol. 70, no. 5, pp. 1741-1779, 2002.

[12] Li, Guangdong., Chuanglin Fang., "Global Mapping and Estimation of Ecosystem Services Values and Gross Domestic Product: A Spatially Explicit Integration of National Green GDP Accounting", Ecological Indicators, vol. 46, pp. 293-314, 2014. 